\title{
The Effect of Give and Go Passing Training and Overlap Passing on Passing Accuracy of Football Player at SSB Putra Bumi Serambi Padang Panjang
}

\author{
A P Pratama \\ Faculty of Sport Science, Universitas Negeri Padang, Prof. Dr. Hamka, Padang, Indonesia \\ *Corresponding author. Email: pratama@fik.unp.ac.id
}

\begin{abstract}
The research problem was the inadequate and limited passing accuracy of SSB Putra Bumi Serambi football player in Padang Panjang. This study aims to determine the effect of giving and go passing training with passing overlap on passing accuracy of SSB Putra Bumi Serambi football player in Padang Panjang.. This research was a quasi-experimental. The population was all football player of SSB Putra Bumi Serambi as many as 52 students. The sampling technique used was purposive sampling so that there was 20 students taken study sample numbered 20 people from SSB Putra Bumi Serambi football school player in Padang Panjang City players. Data collection was done by conducting pre-test and post-test passing accuracy of SSB Putra Bumi Serambi football school player in Padang Panjang City players. Data analysis and hypothesis testing used comparative analysis techniques by using different mean test formula ( $\mathrm{t}$-test) with a significance level of $\alpha=0.05$. From the data analysis carried out the results were obtained: the effect of giving and go passing training with passing overlap on accuracy of the players passing of SSB Putra Bumi Serambi football school player in Padang Panjang City players, with the acquisition of the " $\mathrm{t}$ " test coefficient was tcount = $2.53>$ ttable $=1,729$.
\end{abstract}

Keywords: Give and go passing training, overlap passing, football

\section{INTRODUCTION}

Sport is a medium for people to gather without having to distinguish, race, ethnicity, gender, oldyoung, rich-poor, skin colour, even religion. According to RI Regulation Number Article 3 of 2005 concerning National Sports System: National sports aim to maintain and improve health and fitness, achievement, human quality, instil noble moral and moral values, sportsmanship, discipline, strengthen and foster national unity, strengthen national security, and lift the nation's dignity, dignity and honour. One sport that requires achievement is football.

Along with the development of football, it is necessary to develop and programmed the development and improvement of sports achievements carried out by the government and all levels of society. In order to achieve high achievement, it is necessary to do more effective, efficient and maximum training, especially in the training model, both mastery of basic techniques and excellent physical condition and of course supported by good nutritional status. According to Sneyert in Silitonga (2013: 3), "the quality of the game of a team is determined by the mastery of basic football techniques. The better the technique of mastering the ball by a player, the easier it is for him to be able to escape the pressure of the opponent ". According to Syafruddin (2012: 57) "There are two factors that influence the achievement of an achievement, these factors are internal factors and external factors. Internal factors include; physical, technical, tactical, and mental (psychic) abilities of athletes, and external factors that arise from outside the athlete such as coaches, coaching, climate and weather, nutrition, facilities and infrastructure, organizations, spectators, referees, linesmen, family etc."

At this time, football games are not just entertainment or time killer in leisure time but have been demanded to be of the highest achievement. The problem that occurred was that the SSB Putra Bumi Serambi was well-developed and had gone through programmed and planned training procedures. But besides that, when they play often make their own mistakes such as when passing, then in the form of attacks carried out by SSB Putra Bumi Serambi players often fail, especially when passing the ball. Most players after passing are silent or do not open space to other players, it is not uncommon for players to make non-directed passes so that the ball is easily seized by the opponent. So it's still not so good or still not good at passing between one player and another. 
From the explanation above, the researcher is interested in conducting research on the problems that occur; therefore the authors are interested in conducting research with the title "Effect of exercises give-and-go passing with passing overlap on the accuracy of the passing of SSB Putra Serambi, Padang Panjang City". Based on the problems that have been formulated above, and pay attention to the research variables, this study aims to Reveal: to determine the effect of the practice model give-and-go passing with passing overlap on increasing the accuracy of passing the SSB Putra Serambi players in Padang Panjang City.

According to Muhajir (2007) "Football is a game that is carried out by kicking, which has the goal to put the ball into the opponent's goal by maintaining the goal so as not to concede the ball". Furthermore, Abichandani and Hule (2017) argue that "Football is a sport requiring a great number of technical skills as well as static, semi-dynamic and dynamic balance". The point is that football is a sport that requires static and dynamic technical skills. This means that in football games an athlete is required to have the skills and physical abilities and balance in order to play perfectly.

Accuracy is very important for a football player or other sports athlete. According to Wahjoedi (2001: 61) "accuracy is the ability of the body or limb to direct something according to the desired target". This means that when the body makes a movement such as passing the ball in football, accuracy is needed, because if it is not accurate then the results are not as expected. Furthermore, according to Suharno (1993: 63) accuracy is the ability of a person to direct a motion to the target or target in accordance with their abilities. Accuracy is the ability of a person to do a movement with the direction as desired. From this explanation, it can be understood that the accuracy of passing is the ability of a player to pass with the target as desired, both the ball area and the pass to a friend who moves or who is silent.

In football games, passing is a very important part of some basic football techniques. According to Mielke (2007: 19) "passing is the art of moving a ball from one player to another. According to Danny Mielke (2007: 20), good passing begins when a team that is in possession of the ball creates space between opponents by moving and opening space around the player. Not being able to pass the ball means that you can't play ball. On the other hand, according to Djezed and Dervish in Prengky (2011: 9) "passing is an attempt to move the ball from one place to another using feet or parts of the foot". So, the accuracy of passing is the ability of a player to pass the ball with the direction of the target in accordance with the desired without deviating and optimal. In order to get the accuracy of the ball to a friend when the ball is silent or the ball is (passing accuracy), it is necessary to do an exercise with the correct method of training, the technique of kicking the ball correctly and the exercises carried out repeatedly. Every achievement in the sport, an athlete must do the exercises. Exercise according to Harsono in Lutan, et al (1996: 89) is "a systematic process of practice carried out repeatedly, and more days the amount of training load increases",

Systematic is the exercise carried out in an orderly, planned, continuous, repeated manner the point is that the movements learned must be done repeatedly so that the movements that were originally difficult and the coordination of movements that are still rigid becomes easier in its implementation. And the burden of increasing days means that the training load must be increased regularly because the increased training load will also improve performance. So, with the practice, the goal is not only to improve achievement but also to maintain it.

Based on the description above, the research hypothesis can be formulated as follows: There is an effect of training of passing give and go with passing overlap on the accuracy of passing SSB Putra Bumi Serambi players.

\section{METHODS}

Type of research was a quasi-experimental that aims to reveal the influence of independent variables on the dependent variable (Sugiono, 2011: 74). The independent variable in this study is the method giveand-go passing (X1) and passing overlap (X2) while the dependent variable is passing accuracy $(\mathrm{Y})$.

The population in this study was all SSB Putra Bumi Serambi football school players in Padang Panjang City who were followed in coaching and totalling 52 players. In this study, the sampling technique was purposive sampling. According to Sugiono (2011: 218) "purposive sampling is a technique with certain considerations". The consideration is the purpose and objective characteristics of the sample to be studied. Being a sample is U-15 because it is based on consideration of age, players because the age difference of players will also be a factor that determines the difference in player's abilities. Thus, so that this research can run smoothly, the research sample will be as many as 20 players from SSB Putra Bumi Serambi football school U15.

\section{RESULTS AND RESEARCH}

Data will be described in accordance with the objectives and research hypotheses previously stated. Based on the results of measurements that have been made, namely the Accuracy Test of the passing SSB Putra Bumi Serambi football school player in Padang Panjang City, the initial data (obtained pre-test) and final data (post-test) were. 
Preliminary Data (Pre-Test) Accuracy of passing SSB Putra Bumi Serambi football school Players in Padang Panjang City

Before being given treatment for samples with the practice of Passing Give and go with Passing Overlap, first an initial test of accuracy was carried out passing. In the initial test of 20 samples, the highest score was 107 , the lowest value was 50, with an average value of 81 , and a standard deviation of 14.8 .

Final Data (Post-Test) Accuracy of passing SSB Putra Bumi Serambi football school Players in Padang Panjang City

After being given treatment for samples with Passing Give and go with Passing Overlap for 16 meetings a final test conducted Post-Test accuracy was passing. In the final test, 20 samples were obtained the highest value of 113 , the lowest value 37 , with an average value of 90.95 , standard deviation 16,33.

Before testing the proposed hypothesis, the data analysis requirements test was first done, namely the normality test. Data normality test was carried out using the Liliefors test. For more details the description of the test analysis requirements analysis of the data, it can be seen in the explanation as follows:

Table 1. Summary of Normality Test Data Distribution.

\begin{tabular}{|c|l|c|c|c|c|}
\hline No & \multicolumn{1}{|c|}{ Variable } & $\mathrm{N}$ & Lo & Ltab & $\begin{array}{c}\text { Dist } \\
\text { ribut } \\
\text { ion }\end{array}$ \\
\hline 1 & $\begin{array}{l}\text { Pre-test data before } \\
\text { practice Passing } \\
\text { Give and go } \text { with } \\
\text { Passing Overlap }\end{array}$ & 20 & 0.082 & 0,190 & $\begin{array}{c}\text { Nor } \\
\text { mal }\end{array}$ \\
\hline 2 & $\begin{array}{l}\text { Post-test data after } \\
\text { training Passing } \\
\text { Give and go with } \\
\text { Passing Overlap }\end{array}$ & 20 & 0.115 & 0.190 & $\begin{array}{c}\text { Nor } \\
\text { mal }\end{array}$ \\
\hline
\end{tabular}

The hypothesis proposed in this study is that there is an effective exercise Passing Give and go with Passing Overlap on passing Accuracy in SSB Putra Bumi Serambi football school Players in Padang Panjang City. It can be understood through a summary table of the results of data analysis below:

Table 2. Summary of Results (t-test).

\begin{tabular}{|c|c|c|c|}
\hline \multirow[b]{2}{*}{$\mathrm{Dk}=(\mathrm{N}-1)$} & \multirow[b]{2}{*}{$\mathrm{t}_{\text {count }}$} & t table & \multirow[b]{2}{*}{ Conclusion } \\
\hline & & $\alpha=0.05$ & \\
\hline $20-2=18$ & 2.53 & 1.734 & $\begin{array}{c}\text { Hypothesis } \\
\text { Accepted }\end{array}$ \\
\hline
\end{tabular}

Description:

$\mathbf{t}_{\mathbf{h}}=$ coefficient of test different mean count

$\mathbf{t}_{\mathbf{t a b}}=$ coefficient of test different mean table
Based on these two values, the value of $t_{h}>t_{t}(2.53>$ 1.734). So the proposed hypothesis can be accepted empirically. In conclusion, there is the influence of Passing Give and go with Passing Overlap on Accuracy of passing of SSB Putra Bumi Serambi Football School Players in Padang Panjang City. It means that it can be concluded Passing Give and go with Passing Overlap can improve the accuracy passing of football players.

Based on these findings, it can be concluded that there is an influence of Passing Give and go with Passing Overlap on accuracy passing of football players. For athletes or coaches who want to improve skills passing, then Passing Give and go with Passing Overlap can be a consideration to be used. Because from the results of the research that has been done by Passing Give and go with the Passing Overlap as a whole can improve the Accuracy of the passing SSB Putra Bumi Serambi football school Players in Padang Panjang City. The effectiveness of passing gives and goes with passing overlap on passing accuracy on SSB Putra Bumi Serambi. With the passing practice can improve SSB Putra Bumi Serambi passing accuracy.

\section{CONCLUSION}

Based on the results of data analysis and discussion it can be concluded that there are effects of training passing give and go with passing overlap on Accuracy of passing Putra Bumi Serambi Football School Players (SSB) in Padang Panjang City, with the acquisition of the test coefficient " $\mathrm{t}$ " that is $\mathrm{t}_{\text {count }}=2,53>\mathrm{t}_{\text {table }}=1.734$.

\section{REFERENCES}

[1] Abichandani Deepa \& Vinayak Hule, 2017. Assessment of Anaerobic Power and Balance among Elite Indian Under-19 Football Players. International Journal of Science and Research (IJSR) vol 6 issue 9.

[2] Lutan, Rusli et al. 1996. Human and Sports. Bandung: ITB Publisher.

[3] Mielke, Danny. (2007). Football Basics. Bandung: Raya Expert.

[4] Muhajir. 2007. Physical and Physical Education. Bandung: Yudistira.

[5] Prengky. (2011) "analysis of Basic Passing and Control Techniques of PS Rajawali Regency of South Bengkulu Players" (thesis). Padang: FIK UNP Padang.

[6] Silitonga, Zulhaenri (2013) "Effect of Passing Exercises on the Passing Ability of SSB Imam Bonjol Padang" (thesis) Padang: FIK UNP Padang.

[7] Sugiyono. (2011). Research Methods Quantitative and Qualitative Approaches. Bandung.

[8] Suharno. (1993). Research methodology. Jakarta: Koni Center Jakarta. 
[9] Syafruddin. (2011). Sports Theory and Application Training in Sports Coaching. Padang: Faculty of Sports Sciences, Padang State University.

[10] Syafruddin. (2012). Sports Coaching Sciences. Padang: UNP PRESS.

[11] Law No.3. (2005). About the National Sports System. Jakarta: RI Menpora

[12] Wahjoedi. 2001. Platform for Evaluating Physical Education. Jakarta: Raja Grafindo Persada. 